\title{
The effect of crude protein intake on sperm quality of young and old male broiler breeders
}

\author{
B. Graaf, M. Ciacciariello \& N.C. Tyler \\ Animal and Poultry Science, School of Agricultural, Earth and Environmental Sciences, University of KwaZulu-Natal, \\ P. Bag X01, Scottsville, 3209, Pietermaritzburg, South Africa
}

(Received 20 December 2017; Accepted 18 September 2018; First published online 20 December 2018)

Copyright resides with the authors in terms of the Creative Commons Attribution 4.0 South African License.

See: http://creativecommons.org/licenses/by/4.0/za

Condition of use: The user may copy, distribute, transmit and adapt the work, but must recognize the authors and the South African Journal of Animal Science

\begin{abstract}
This experiment compared fertility of male broiler breeders with different crude protein (CP) intakes from diets containing 9.7\%, 11.7\% and 13\% CP from 27 to 60 weeks of age (in two phases) and in a different group of birds from 52 to 60 weeks of age. This was to assess fertility of males with different CP intakes, as well as comparing fertility in older birds having been fed different protein intakes throughout production to those on a commercial ration for most of production. Sperm concentration and sperm mobility were assessed, as well as the number of points of hydrolysis in the inner-perivitelline membrane of eggs from commercial egg-type hybrids after insemination, which was used to predict egg fertility. There was no response to $\mathrm{CP}$ intake observed in sperm concentration or sperm mobility at any age. A positive effect of $\mathrm{CP}$ intake was observed in egg fertility towards the end of the production phase. While broiler breeder producers make use of separate sex feeding, the female ration is often fed to males in the appropriate amounts to achieve growth according to the target for males. However because it would be cheaper to include less $\mathrm{CP}$ in the ration, the effect of $\mathrm{CP}$ on breeder fertility is important. This experiment showed that reducing $\mathrm{CP}$ to $117 \mathrm{~g} / \mathrm{kg}$ in male broiler breeder rations fed throughout the production phase had minimal negative effects on sperm quality, however, increasing CP intake towards the end of production may positively impact egg fertility.
\end{abstract}

Keywords: Fertility, insemination, mobility, poultry

\# Corresponding author: tyler@ukzn.ac.za

\section{Introduction}

Despite the use of separate sex feeding, many producers feed a female ration to both male and females, at different intakes, calculated to allow adherence to the growth curve for each. While this may be of practical value, crude protein (CP) is one of the most costly components of the feed, and the nutrient requirement of males for protein is lower than that of females. Previous research has suggested that male breeders can be fed lower CP diets with no adverse effects on semen quality or testes characteristics (Wilson et al., 1988, Hocking, 1989, Revington et al., 1991). There was no effect of feeding of a 9\% CP diet on semen volume, concentration, number of spermatozoa per ejaculate or testes weight (Wilson et al., 1987), or feeding an $8 \%$ CP diet on semen volume or metabolic activity of spermatozoa (Hocking, 1989). No differences in semen concentration or egg fertility were observed after feeding males a $12 \%$ or $14 \%$ CP diet (Fontana et al., 1990). However, male broiler breeders fed $12.6 \%$ CP produced sperm that resulted in a longer fertile period after insemination than those fed 10.5\% and 15\% CP (Tyler \& Bekker, 2012). Other negative reports of feeding an excess of CP include those of Hocking (1989) where the proportion of males producing semen declined with an increase in CP intake, and sperm concentration and testicular function were reduced in males fed a 16\% CP diet (Hocking \& Bernard, 1997). Males fed a low CP diet (11\%) also showed a slower age-related decline in fertility than those fed a 16\% CP diet (Hocking, 1990). Those fed excessive CP (40\%) developed articular gout and were culled at 39 weeks (Hocking, 1989).

Crude protein is one of the most costly components of poultry feed and protein which is not utilised in body gains or production cannot be stored and has to be converted into uric acid and eliminated from the body, a process that requires energy, which could result in a relative energy deficiency. There are also 
environmental concerns about nitrogen losses in animal waste and the resultant negative impact on fresh water supplies, and broiler breeders fed excess protein or feeds with an incorrect amino acid profile will excrete the excess nitrogen and feeding a diet lower in CP can reduce this (Lopez \& Leeson, 1995).

To date, there is no research investigating the effects of $\mathrm{CP}$ intake during the production phase on fertility of broiler breeder males using more recent sperm quality measures, such as sperm mobility or points of sperm hydrolysis in the inner perivitelline layer (IPVL). These measures are thought to be more indicative of fertilising potential as they are actually indicators of sperm sequestration within the sperm storage tubules in the hen (Froman \& McLean, 1996). The advantage of assessing IPVL holes in eggs from commercial eggtype hybrids after insemination is that variation in female fertility is much reduced compared to assessing fertility using broiler breeder females.

For ease of management, males are often fed a female diet, which has a higher CP content. A high $\mathrm{CP}$ (female breeder) diet fed to the males during the breeding period was associated with a decline in fertility from 45 to 60 weeks of age (WOA) compared with that of males fed a low CP diet (Hocking, 1990), which could have negative consequences on flock fertility.

Therefore, the objective of this experiment was to evaluate the effect of three different dietary CP levels on male broiler breeder fertility in the production phase, assessed by sperm concentration, sperm mobility and sperm penetration holes of the IPVL of oviposited eggs of commercial egg-type females after insemination.

\section{Materials and Methods}

One hundred and forty-four Ross 308 broiler breeder males, 72 at 27 WOA (Group A) and 72 at 52 WOA (Group B) were placed in individual cages $(60 \mathrm{~cm}$ wide $\times 44 \mathrm{~cm}$ deep $\times 60 \mathrm{~cm}$ high) in one of 6 lighttight rooms (12 birds per room). Birds were provided with a $13 \mathrm{~h}$ photoperiod (06:00 to 19:00) after having been reared on a $9 \mathrm{~h}$ photoperiod (Lewis et al., 2008). Two groups of males of different ages were used to determine whether changing diets towards the end of production, when fertility traditionally declines, would be different to having been on a standard CP intake from soon after the start of production.

Prior to the start of the experiment (from 20 WOA for Group A birds and 35 WOA for Group B birds) a commercial breeder feed (130 g CP/ $\mathrm{kg}, 11.7 \mathrm{MJ} \mathrm{ME} / \mathrm{kg}$ ) was provided. The birds were weighed individually every two weeks and the feed allocation for the Group A and Group B males adjusted to adhere to the growth curve recommended by the primary breeder. During this time birds were trained to produce a semen sample which was analysed for mobility (Froman \& McLean, 1996) using a Turkey Mobility Analyser 591B (ARS, Chino, CA), calibrated for use in chickens. The 72 Group A males were selected from 79 and the 72 Group B males from 122. Those with the highest mobility scores with a body weight (BW) close to that recommended by the primary breeder were selected in an attempt to reduce variation between birds. Males in each age group were ranked according to sperm mobility index and placed in rooms, such that the first 12 birds with the highest mobility scores were allocated to rooms 1 to 12 , the next 12 birds then allocated to rooms 1 to 12, until all birds had been allocated to rooms.

The birds were provided with ad libitum access to water throughout the experimental period and randomly allocated to one of three dietary treatments (a low, medium or high CP diet, respectively) within a room (4 birds/room on each treatment). Two iso-energetic diets were formulated to contain either low protein or high protein. Except for the $\mathrm{CP}$, both diets were formulated according to the breeder nutrient specifications of a male breeder feed from 24 weeks onwards (Aviagen, 2007). A third intermediate diet was then blended from the high and low protein diets. A sample of each experimental diet was then analysed for nutrient composition (Table 1). This resulted in the three diets containing 9.7\%, 11.7\% and 13\% CP (Table 1).

The Group A males were allocated $130 \mathrm{~g} / \mathrm{bird} / \mathrm{day}$ from 27 - 41 WOA (phase 1) and $142 \mathrm{~g} / \mathrm{bird} / \mathrm{d}$ from 42 - 60 WOA (phase 2). The Group B males received a feed allocation of $145 \mathrm{~g} / \mathrm{bird} /$ day from 52 to 60 WOA. This resulted in a daily CP intake of 12.6, 15.2 and $16.9 \mathrm{~g}$ for the Group A males (phase 1), 13.7, 16.6 and $18.5 \mathrm{~g}$ for the Group A males (phase 2) and 14.0, 17.0 and $18.9 \mathrm{~g}$ for the Group B males and a cumulative $\mathrm{CP}$ intake (during the experimental period) of 3057,3697 and $4117 \mathrm{~g}$ CP for the Group A males (phase 1 and 2) and 784, 952 and $1058 \mathrm{~g}$ CP for the Group B males.

Semen samples from the Group A males were collected for analysis at 27, 29, 32, 35, 41, 47, 52, 55, 58 , and 60 WOA and at 52, 54, 57, and 60 WOA for the Group B males. The semen from males on the same treatment in each room was pooled prior to analysis. Each sample was tested for sperm concentration and sperm mobility index (Froman \& McLean, 1996) using a Turkey Mobility Analyser Model 591B (Animal Reproduction Systems, Chino, CA), calibrated for use in chickens. The sample was then diluted (Poultry Motility buffer (Animal Reproduction Systems, Chino, CA) to contain 100 million sperm/50 $\mu \mathrm{L}$. One hundred and eighty commercial Lohmann egg-type hens were used to test the fertility of the sperm. This was to reduce the female bias on fertility as commercial egg-type hens are known to have high fertility. The hens 
Table 1 The ingredients of the formulated rations and analysed nutrient contents (units specified) of the low, medium and high crude protein diets

\begin{tabular}{|c|c|c|c|c|}
\hline Ingredient & Unit & Low & Medium & High \\
\hline Maize & $\mathrm{g} / \mathrm{kg}$ & 704 & & 645 \\
\hline Wheat bran & $\mathrm{g} / \mathrm{kg}$ & 169 & & 200 \\
\hline Soya bean 46 & $\mathrm{~g} / \mathrm{kg}$ & & & 118 \\
\hline Sunflower 34 & $\mathrm{~g} / \mathrm{kg}$ & 39.1 & & \\
\hline L-lysine HCL & $\mathrm{g} / \mathrm{kg}$ & 0.90 & & 0.06 \\
\hline DL methionine & $\mathrm{g} / \mathrm{kg}$ & & & 0.07 \\
\hline Vitamin \& mineral premix & $\mathrm{g} / \mathrm{kg}$ & 2.50 & & 2.50 \\
\hline Filler (sand) & $\mathrm{g} / \mathrm{kg}$ & 40.0 & & \\
\hline Limestone & $\mathrm{g} / \mathrm{kg}$ & 19.7 & & 19.5 \\
\hline Salt & $\mathrm{g} / \mathrm{kg}$ & 1.47 & & 2.67 \\
\hline Sodium bicarbonate & $\mathrm{g} / \mathrm{kg}$ & 5.60 & & 1.27 \\
\hline Oil- sunflower & $\mathrm{g} / \mathrm{kg}$ & 8.85 & & 7.88 \\
\hline Kynofos & $\mathrm{g} / \mathrm{kg}$ & 8.95 & & 3.86 \\
\hline \multicolumn{5}{|l|}{ Nutrient composition (as is) } \\
\hline AMEn adult & $\mathrm{MJ} / \mathrm{kg}$ & 12.3 & 12.2 & 12.2 \\
\hline Crude protein & $\%$ & 9.68 & 11.7 & 13.0 \\
\hline Dry matter & $\%$ & 89.1 & 88.9 & 88.4 \\
\hline Moisture & $\%$ & 10.9 & 11.1 & 11.6 \\
\hline Calcium & $\%$ & 0.95 & 0.85 & 0.88 \\
\hline Phosphorus (total) & $\%$ & 0.69 & 0.52 & 0.58 \\
\hline Methionine & $\%$ & 0.18 & 0.21 & 0.23 \\
\hline Cysteine & $\%$ & 0.21 & 0.23 & 0.26 \\
\hline Methionine + Cysteine & $\%$ & 0.39 & 0.44 & 0.49 \\
\hline Lysine & $\%$ & 0.37 & 0.51 & 0.61 \\
\hline Threonine & $\%$ & 0.34 & 0.42 & 0.49 \\
\hline Arginine & $\%$ & 0.57 & 0.72 & 0.84 \\
\hline Isoleucine & $\%$ & 0.33 & 0.43 & 0.50 \\
\hline Leucine & $\%$ & 0.94 & 1.09 & 1.17 \\
\hline Valine & $\%$ & 0.45 & 0.55 & 0.63 \\
\hline Histidine & $\%$ & 0.25 & 0.31 & 0.35 \\
\hline Phenylalanine & $\%$ & 0.46 & 0.56 & 0.63 \\
\hline Glycine & $\%$ & 0.44 & 0.52 & 0.58 \\
\hline Serine & $\%$ & 0.45 & 0.55 & 0.63 \\
\hline Proline & $\%$ & 0.73 & 0.83 & 0.93 \\
\hline Alanine & $\%$ & 0.60 & 0.68 & 0.73 \\
\hline Aspartic acid & $\%$ & 0.69 & 0.95 & 1.15 \\
\hline Glutamic acid & $\%$ & 1.80 & 2.14 & 2.40 \\
\hline
\end{tabular}

AMEn: nitrogen-corrected apparent metabolizable energy

were 37 WOA at first insemination and housed in cages (50 cm wide $\times 50 \mathrm{~cm}$ deep $\times 50 \mathrm{~cm}$ high) containing either two or three birds per cage (with birds in a cage all inseminated with semen from males on the same treatment). Each were inseminated with a $50 \mu \mathrm{L}$ volume of semen (100 million sperm) resulting in 5 hens per replication. Eggs were collected on days 2, 5 and 8 post-artificial insemination (PAI) and stored in a cold room at an average of $14{ }^{\circ} \mathrm{C}$ for no more than two weeks before being assessed for the number of points of 
sperm hydrolysis in the IPVL (Bramwell et al., 1995). The slides were examined on the same day they were prepared using a light microscope $(4 \times$ magnification) and captured with a digital camera. The points of sperm hydrolysis were counted in a $4 \mathrm{~mm}^{2}$ area around the germinal disc and the number of points of sperm hydrolysis per $\mathrm{mm}^{2}$ was calculated. Wishart (1997) showed that eggs had maximum fertility when more than six spermatozoa per $\mathrm{mm}^{2}$ penetrated the IPVL around the germinal disc, so the fertility of each egg, based on the number of sperm holes, was predicted.

There were no mortalities recorded in either group for the duration of the trial. At 63 WOA the Group B males were euthanized by electrical stunning and severing of the jugular vein, and the testes removed and weighed. Ethical approval for this study was granted by the UKZN Animal Ethics Committee (Ref 094/12).

Body weights at each 2-week interval were subjected to a general ANOVA to determine if there were any differences in BW with CP intake over the experimental period for each group of birds, as well as simple linear regression to determine if there was any response in BW to CP intake. Simple linear regression was performed to determine if there was a response in sperm concentration and sperm mobility to CP intake at each collection time and within Group A males (phase 1), Group A males (phase 2), and Group B males. This also included the same regressions for cumulative CP intake of birds in each group/phase. GenStat 17 was used for these analyses (VSN International Ltd, 2014).

A binary logistic regression using SPSS Statistics 22 (IBM, 2013) was performed to determine the effect of CP intake on the predicted fertility of eggs for the Group A males (phase 1 and 2) and the Group B males at each day post-insemination (2, 5 , and 8 days). The data for the IPVL holes were not normally distributed and no transformation provided a normal distribution; therefore, analysis was only performed on the prediction of egg fertility from this data.

The average testes weights from birds on each treatment were subjected to a general ANOVA. The left and right testes weights (Group B males) from birds on different treatments were compared by performing a paired t-test using GenStat 17 (VSN International Ltd, 2014).

\section{Results and Discussion}

Overall, there was no significant response seen in BW to CP intake in both phases in the Group A males as well as in the Group B males. However, at 40 WOA the Group A males in phase 1 fed the high CP diet had a significantly lower $(P<0.05)$ BW than the birds on the low and medium CP diets, and to the breeder recommended weight. However, when feed allocation was increased at 42 WOA, these birds rejoined the standard curve and no significant difference in BW between birds fed different CP diets was observed at any other stage. Adherence to the recommended BW growth curve during rear is necessary. Breeders reared on a concave growth curve (under target in early rearing and then increased feed allocation towards the end of rearing) required more energy ( $15 \mathrm{kcal} \mathrm{ME} /$ male/day) to sustain fertility after 40 weeks of age (Romero-Sanchez et al., 2007). Avoiding excess BW in the production phase is also important, as a lack of control is an important cause of the age-related decline in fertility (Hocking \& Duff, 1989), associated with musculoskeletal lesions and broad-breasted males who may find it anatomically difficult to achieve cloacal contact with hens, thereby reducing fertility.

The only significant response in sperm concentration to CP intake was observed in the Group A males at 27 weeks of age $(P<0.05)$ where a slight negative slope $(-0.18)$ was observed, but only $28 \%$ of the variance was accounted for. No significant response in sperm mobility to CP intake was observed at any collection time. No significant response in sperm concentration or sperm mobility index to cumulative CP intake was observed in any of the groups. The lack of response in sperm concentration to CP intake is similar to that observed by Wilson et al. (1988) and Revington et al. (1991). Sperm mobility, however, has not previously been used to assess the impact of CP intake, and the results from this experiment show no response in sperm mobility index to CP intake. Froman \& Feltmann (1998) showed that males classified as having either high or average sperm mobility phenotypes remained in the same classification over time, so it is possible that the phenotypic expression of the sperm mobility genotype of a bird may not be influenced much by environmental factors, such as feeding regime. Thus, it appears that at the CP intakes used in this experiment, no effect at the cellular level was observed and there was no influence of CP intake on either the sperm concentration or the sperm mobility, which is considered a more accurate measure of fertilising potential of the sperm produced.

There was also no significant effect of $\mathrm{CP}$ intake on the number of predicted fertile eggs (those with $>6$ sperm holes per $\mathrm{mm}^{2}$ ) at day 2,5 or 8 PAl in the Group A males (phase 1) and CP intake contributed negligibly to variance in egg fertility. However, in older birds (Group A males phase 2 and Group B males), a significant $(P<0.05)$ positive effect of CP intake was observed on predicted egg fertility at day 2, 5 and 8 PAI (except at day 8 PAl in Group A males phase 2) (Table 2). These models correctly classified between 59\% and $79 \%$ of predicted egg fertility, and eggs were up to 1.39 times more likely to be fertile per unit increase in CP intake; however, in each case, the model only explained between $1 \%$ and $10 \%$ of the variance in egg 
fertility and therefore should be interpreted with caution. The slight benefit in a higher CP intake seen in prediction of fertile eggs could indicate the need to increase CP intake as birds age, due to the likely decrease in efficiency of utilisation of amino acids which is observed in laying hens (Wethli \& Morris, 1978, Silva et al., 2014) and possibly female broiler breeders (Ciacciariello et al., 2013). Romero-Sanchez et al. (2008) also suggested that the decline in fertility can be reduced by increased feed allocation later in production, which would allow for a decrease in utilisation of feed, but the increase in BW could also negatively affect mating ability, and therefore an increase in CP content of the diet would be of greater advantage than a feed allocation increase. These results also indicate that the potential benefit would be regardless of previous $\mathrm{CP}$ intake, with a benefit seen in birds fed a commercial ration until 52 weeks of age, as well as those fed different CP treatments from 27 weeks of age.

Table 2 The results of the prediction of egg fertility (from the IPVL holes per $\mathrm{mm}^{2}$ ) per unit increase in CP intake in broiler breeder males of different ages

\begin{tabular}{lcccc}
\hline & Day PAI & $\mathbf{R}^{2}$ & Odds ratio & $P$-value \\
\hline & 2 & 0.00 & 0.988 & 0.850 \\
Group A males, phase 1 (27 - 41 weeks of age) & 5 & 0.00 & 0.992 & 0.896 \\
& 8 & 0.00 & 1.029 & 0.706 \\
Group A males, phase 2 (47 - 60 weeks of age) & 2 & 0.03 & 1.16 & 0.008 \\
& 5 & 0.03 & 1.18 & 0.006 \\
Group B males (52 - 63 weeks of age) & 8 & 0.01 & 1.08 & 0.281 \\
& 2 & 0.05 & 1.24 & 0.004 \\
& 5 & 0.04 & 1.18 & 0.013 \\
& 8 & 0.10 & 1.39 & 0.000 \\
\hline
\end{tabular}

PAI: post-artificial insemination; IPVL: inner perivitelline layer

There was no significant difference in the average testes weight in males with different CP intake, indicating that semen production was not influenced by CP intake. However, the average left and right testis weights were significantly different in birds fed 14.0 and $18.9 \mathrm{~g} \mathrm{CP}$ per day from 52 to 63 weeks of age $(P$ $<0.05$ ), but not in birds fed $17.0 \mathrm{~g} \mathrm{CP}$ per day from 52 to 63 weeks of age (Table 3). Asymmetry may be an indicator of stress (Yang \& Siegel, 1998), which could imply that the medium CP intake was more beneficial than the lower or higher intake. However, a number of studies have reported heavier left testis weights in broiler breeders (Wolanski et al., 2004, Tyler \& Gous, 2009) with no negative impact on fertility. The asymmetry observed at the lower and higher CP intakes could also have been present before 52 weeks of age before dietary treatments were started in these birds.

Neither the lowest level of dietary CP used in this experiment, formulated to be at the lower limits of practical value, or the high protein diet, formulated to result in a protein intake similar to that provided by a female breeder ration, impacted fertility negatively during production; however, protein deficiencies may have a more pronounced affect during rearing and development, and at the end of production.

Table 3 Left and right testis weights ( \pm SEM) of Group B birds $(n=72)$ at 63 weeks of age after different crude protein (CP) intakes from 52 to 63 weeks of age

\begin{tabular}{lccc}
\hline $\begin{array}{c}\text { CP intake (g/d) from } \\
\mathbf{5 2}-\mathbf{6 3} \text { weeks of age }\end{array}$ & $\begin{array}{c}\text { Left testis weight } \\
(\mathbf{g})\end{array}$ & $\begin{array}{c}\text { Right testis weight } \\
\mathbf{( g )}\end{array}$ & $\boldsymbol{P}$-value \\
\hline & & & \\
14.0 & $17.75( \pm 0.80)$ & $16.34( \pm 0.69)$ & 0.001 \\
17.0 & $16.07( \pm 1.16)$ & $15.08( \pm 1.02)$ & 0.083 \\
18.9 & $16.20( \pm 0.77)$ & $14.84( \pm 0.75)$ & 0.005 \\
\hline
\end{tabular}


While little research in poultry was found regarding the role of protein in reproductive tract development, protein plays a role in the development of seminiferous tubules in rats, where protein deficiencies during development led to reduced seminiferous tubule diameter, reduced epithelial cell height, as well as reductions in testicular DNA and RNA (Vawdaw \& Mandlwana, 1990). The role of proteins has been shown in the maturation of sperm in the human epididymis (Kirchhoff et al., 1998, Moskovtsev et al., 2007), as well as the prevention of spermatozoal defects in humans (Zhao et al., 2004). A 12\% CP diet was not shown to be deficient in rearing, where male broiler breeders had significantly greater fertility throughout the production period than those fed $17 \%$ CP in rear (Romero-Sanchez et al., 2007). Those fed higher CP in rear also required more energy later in production to sustain fertility. While the body weights were higher in these birds during rear, the drop in fertility during production was not attributed to a higher maintenance cost, because body weights were not significantly different after 32 weeks of age.

The amino-acid profile has also been shown to influence sperm quality in monkeys. When monkeys were fed high levels of protein, the source of protein (animal versus plant-based) had no significant effect on sperm quality parameters, but when levels of protein in the diet were reduced, those fed animal-based protein diets had lower sperm counts, reduced sperm motility and greater morphological defects. This indicates that perhaps the amino acid profile, with fewer sulphur-containing amino acids found in plant-based proteins, are more beneficial to sperm quality (Johnson \& Veith, 2001).

Potential limitations to this study include that broiler breeder males were caged individually so there are no behavioural considerations taken into account, such as hierarchy set up or mating behaviour, that are known to influence fertility.

\section{Conclusion}

There was no conclusive evidence that lower CP intakes had a negative effect on male broiler breeder fertility or body weight, and therefore it may be cost-effective to feed males a separate feed, formulated to contain less CP, than feeding a female ration, although feeding a typical female ration should not have negative consequences on fertility either. It is possible that increasing the CP intake towards the end of production could reduce the decline in fertile egg production as bird's age.

\section{Acknowledgements}

The authors are grateful to the NRF for a scare skills bursary awarded to BG, the PRF for funding towards the experimental work, and the staff at the Microscopy and Microanalysis Unit at UKZN. This paper is published as part of a MSc Agric thesis by BG.

\section{Authors' Contributions}

BG conducted most of the experimental work as part of a MSc Agric degree under the supervision of NT and MC. Manuscript preparation was undertaken by NT and MC.

\section{Conflict of Interest Declaration}

There was no conflict of interest.

\section{References}

Aviagen, 2007. Ross 308 Parent stock nutrient specifications. Aviagen Group: AL, USA.

Bramwell, R.K., Marks, H.L. \& Howarth, B., 1995. Quantitative determination of spermatozoa penetration of the perivitelline layer of the hen's ovum as assessed on oviposited eggs. Poult. Sci. 74, 1875-1883.

Ciacciariello, M., Tyler, N.C. \& Khetani, T.L., 2013. The effects of maternal dietary lysine intake on offspring performance to 21 days of age. J. Appl. Poult. Res. 22, 238-244.

Fontana, E.A., Weaver, W.D. \& van Krey, H.P., 1990. Effects of various feeding regimens on reproduction in broilerbreeder males. Poult. Sci. 69, 209-216.

Froman, D.P. \& McLean, D.J., 1996. Objective measurement of sperm motility based upon sperm penetration of Accudenz®. Poult. Sci. 75, 776-784.

Froman, D.P. \& Feltmann, A.J., 1998. Sperm mobility: a quantitative trait of the domestic fowl (Gallus domesticus). Biol. Reprod. 58, 379-384.

Hocking, P.M., 1989. Effect of dietary crude protein concentration on semen yield and quality in male broiler breeder fowls. Br. Poult. Sci. 30, 935-945.

Hocking, P.M., 1990. The relationships between dietary crude protein, body weight, and fertility in naturally mated broiler breeder males. Br. Poult. Sci. 31, 743-757.

Hocking, P.M. \& Bernard, R., 1997. Effects of dietary crude protein content and food intake on the production of semen in two lines of broiler breeder males. Br. Poult. Sci. 38, 199-202.

Hocking, P. \& Duff, S.R. 1989. Musculo-skeletal lesions in adult male broiler breeder fowls and their relationships with body weight and fertility at 60 weeks of age. Br. Poult. Sci. 30, 777-784.

IBM, 2013. SPSS Statistics for Windows, Version 22.0. Armonk, NY: IBM CorSPSS statistics version 22. 
Johnson, Q. \& Veith, W., 2001. Effect of dietary plant and animal protein intake on sperm quality in monkeys. Arch. Androl. 46, 145-151.

Kirchhoff, C., Osterhoff, C., Pera, I. \& Schröter, S., 1998. Function of human epididymal proteins in sperm maturation. Andrologia 30, 225-232.

Lewis, P.D., Tyler, N.C., Gous, R.M., Dunn, I.C. \& Sharp, P.J., 2008. Photoperiodic response curves for plasma Ih concentrations and age at first egg in female broiler breeders. Anim. Reprod. Sci. 109, 274-286.

Lopez, G. \& Leeson, S., 1995. Response of broiler breeders to low-protein diets.: 1. Adult breeder performance. Poult. Sci. 74, 685-695.

Moskovtsev, S.I., Jarvi, K., Légaré, C., Sullivan, R., Brendan, J. \& Mullen, M., 2007. Epididymal p34h protein deficiency in men evaluated for infertility. Fertil. Steril. 88, 1455-1457.

Revington, W.H., Moran, E.T. \& McDaniel, G.R., 1991. Performance of broiler breeder males given low protein feed. Poult. Sci. 70, 139-145.

Romero-Sanchez, H., Plumstead, P.W. \& Brake, J., 2007. Feeding broiler breeder males. 1. Effect of feeding program and dietary crude protein during rearing on body weight and fertility of broiler breeder males. Poult. Sci. 86, 168-174.

Romero-Sanchez, H., Plumstead, P.W., Leksrisompong, N., Brannan, K.E. \& Brake, J., 2008. Feeding broiler breeder males. 4. Deficient feed allocation reduces fertility and broiler progeny body weight. Poult. Sci. 87, 805-811.

Silva, E.P., Sakomura, N.K., Dorigam, J.C.P., Malheiros, E.B., Fernandes, J.B.K. \& Araujo, J.A., 2014. A procedure to evaluate the efficiency of utilization of dietary amino acid for poultry. Acta Sci. Anim. Sci. 36, 163-169.

Tyler, N.C. \& Bekker, H.A., 2012. The effect of dietary crude protein on the fertility of male broiler breeders. S. Afr. J. Anim. Sci. 42, 304-309.

Tyler, N.C. \& Gous, R.M., 2009. The effect of age at photostimulation of male broiler breeders on testes growth and the attainment of sexual maturity. S. Afr. J. Anim. Sci. 39, 169-175.

Vawdaw, A.I. \& Mandlwana, J.G., 1990. The effects of dietary protein deficiency on rat testicular function: Der einfluß einer proteinarmen diät auf die hodenfunktion der ratte. Andrologia 22, 575-583.

VSN International, 2014. GenStat for Windows 17th Edition. VSN International, Hemel Hempstead, UK. Web page: GenStat.co.uk.

Wethli, E. \& Morris, T.R., 1978. Effects of age on the tryptophan requirement of laying hens. Br. Poult. Sci. 19, 559-565.

Wilson, J.L., McDaniel, G.R., Sutton, C.D. \& Renden, J.A., 1987. Semen and carcass evaluation of broiler breeder males fed low protein diets. Poult. Sci. 66, 1535-1540.

Wilson, J.L., Krista, L.M., McDaniel, G.R. \& Sutton, C.D., 1988. Correlation of broiler breeder male semen production and testes morphology. Poult. Sci. 67, 660-668.

Wishart, G.J., 1997. Quantitative aspects of sperm:egg interaction in chickens and turkeys. Anim. Reprod. Sci. 48, 81-92.

Wolanski, N.J., Renema, R.A., Robinson, F.E. \& Wilson, J.L., 2004. End-of-season carcass and reproductive traits in original and replacement male broiler breeders. J. Appl. Poult. Res. 13, 451-460.

Yang, A. \& Siegel, P.B., 1998. Asymmetries and heterosis of bilateral traits in parental lines of chickens and their f1 crosses. J. Anim. Breed. Genet. 115, 105-111.

Zhao, M., Shirley, C.R., Hayashi, S., Marcon, L., Mohapatra, B., Suganuma, R., Behringer, R.R., Boissonneault, G., Yanagimachi, R. \& Meistrich, M.L., 2004. Transition nuclear proteins are required for normal chromatin condensation and functional sperm development. Genesis 38, 200-213. 